European Commission clarifies the rules for research audits

As the member of the European Commission responsible for research, innovation and science, I would like to correct inaccurate claims in your Editorial on the Sixth Framework Programme (FP6) (Nature 465, 666; 2010).

Your discussion is based on several misunderstandings of the rules governing research funding in the European Union (EU) and of the way they are operating with respect to recent FP6 audits. You claim that "several national research agencies have been accused of cheating by the European Commission", which is untrue and damaging for both the commission and the agencies.

The commission's auditing is done to ensure that public money is properly managed and that errors are corrected. Making errors is not the same as cheating. In rare instances in which cheating is suspected, we refer cases to OLAF, the EU's fraud-investigation arm.

The programme did not close in 2006, as you say: some FP6 projects launched in 2006 will run until 2011 and, according to the contracts signed by the participants, are auditable for five years after their conclusion.

Your repeated references to 're-auditing' and 'reinterpretation' of FP6 projects is misleading. Funds are only ever audited once by the commission and - to make life easier for beneficiaries - always after they have been claimed. Corrections can therefore only be proposed afterwards. At no stage under the FP6 or any other programme have 'customary practices' been approved and then refused. Neither is the commission 'reinterpreting' the FP6 rules: it is applying the rules, as it is legally bound to do.

I agree that we need to minimize line-by-line auditing of individual projects. That is why the rules stipulate that if a beneficiary is found to have made the same errors in a sample of projects, the commission assumes that those errors were also made regarding its participation in all comparable projects. But beneficiaries may contest this and ask for detailed audits.

As for the commission issuing a "proclamation that only errors in its own favour are subject to correction", there was no such proclamation. Since 2005, more than 400 adjustments have been made in favour of participants who had made errors to their own disadvantage, amounting to about $€ 23$ million (US $\$ 29$ million) in additional payments. Other adjustments are pending and are always made when funds are available.

I do not think it is necessary, in order to make the case for further simplifying the rules, to resort to distortion and exaggeration. But I do agree that more needs to be done. This is a top priority for me, and the new commission has already put forward important measures, including changes to the financial regulation and proposing that a "tolerable risk of error" of $2-5 \%$ should be applied to research projects.

I have made my intention to deliver further simplification very clear, building on the work already done by my predecessor Janez Potočnik, with the support of the departing director-general of DG Research, José Manuel Silva Rodríguez.

I take this opportunity to warmly thank Mr Silva Rodríguez for his major contribution to European research policy through his successful stewardship of DG Research over nearly five years.

Máire Geoghegan-Quinn European Commission, 1049 Brussels, Belgium e-mail: cab-geoghegan-quinncontact@ec.europa.eu

Editorial note: Nature stands by the opinions in its Editorial.

\title{
Nature's readers comment online
}

\section{A selection of responses posted on Nature's website to the News article 'Strikes could "break" Italy's universities' (Nature 466, 16-17; 2010).}

\section{Giampaolo Minetti said:}

What the Italian ricercatori (researchers), including myself, are threatening is not a strike. Although ricercatori are not obliged to teach, in practice they run a significant proportion of science courses - but why do they do this? According to the rules, a ricercatore is permitted to teach voluntarily and occasionally, although unpaid and in addition to his or her research duties. However, this practice is running out of control, to the point at which more than $30 \%$ of teaching is now done by the ricercatori.

To protest against the government's budget cuts and the reform bill, we resolved to stick to the rules and decline any offers to teach. We will continue to do what we are paid for, namely research and associated duties (including giving seminars, tutoring students and participating in examining committees). We are also contributing to proposals for alternative university reforms through a group of organized researchers (the 'Rete29Aprile'). Our strategy is by no means a strike, but a last resort against the new reform bill, which threatens to dismantle the country's public university system. e-mail:minetti@unipv.it

\section{Patrizio Dimitri and Patrizia Lavia said:}

The list of measures about to be approved by Italy's government includes indiscriminate heavy cuts to public universities and public research. Those cuts will come after years of decline in research funding and will be made in the absence of any serious, internationally recognized system of evaluation of research and teaching quality.

The Italian research and university system undoubtedly needs a cure, but the remedy should not kill the patient. There should be a rigorous, strict and transparent evaluation system to cut unproductive areas and hit the existing areas of laziness and nepotism headon. Without such a merit-based approach, indiscriminate cuts by Silvio Berlusconi's government will penalize the active and vital components of Italy's universities and research centres, whose scientists desperately strive to keep doing research and producing results. e-mail:patrizio.dimitri@uniroma1.it

\section{Michael Shore said:}

In this complex situation, there are no heroes, just villains. Italy's continuous drastic budget cuts threaten to destroy its public university teaching and research. But before pointing fingers, the Italian university system should point a few thumbs - at itself. It is an institution plagued by phenomenal inbreeding (how many faculty members have a cradle-to-grave career, from undergraduate to retirement, in the same university?), little or no meritocracy (how convenient to get automatic raises every two years, regardless of productivity) and no real desire for improvement (rhetoric aside, most counter-proposals aim only to preserve the status quo).

e-mail:michael.shore@verizon.net

Readers can comment online on anything published in Nature. To join this debate, go to http://go.nature.com/Eumhhm. 